\title{
High resolution mapping of community structure in three glass sponge reefs (Porifera, Hexactinellida)
}

\author{
Jackson W. F. Chu, Sally P. Leys* \\ Department of Biological Sciences, CW 405, University of Alberta, Edmonton, Alberta T6G 2E9, Canada
}

\begin{abstract}
Glass sponge reefs (Porifera, Hexactinellida) are unique to the Pacific coast of Canada. To date, the locations and extents of reefs have only been assessed by multibeam echosounders, a method that does not resolve where live, dead and buried sponges are within a reef. We performed fine-scale (25 and $12.5 \mathrm{~m}$ grids) photographic surveys using remote operated vehicles and carried out GIS and semivariogram analysis to produce high resolution maps of the spatial distribution and abundance of glass sponges among 3 reefs in the Strait of Georgia and also to determine the community structure of animals associated with the reefs. Within a reef, glass sponges are clustered in spatially dependent patches 35 to $72 \mathrm{~m}$ in diameter, which we interpret to result from growth and reproduction processes. Reefs occur within a narrow range of depths (30 to $50 \mathrm{~m}$ ), which may be explained by suspension feeding requirements for flow, which is accelerated over the underlying elevated bedrock mounds and ridges. The local abundance of fish and crustaceans was significantly higher in the presence of glass sponges while significantly lower abundances of molluscs and other sponges were found within the reefs. Also, we determined that a dense population of reef sponges can process water at $83000 \mathrm{l} \mathrm{s}^{-1}$, removing carbon at a rate of $0.96 \mathrm{~g} \mathrm{C} \mathrm{m}^{-2} \mathrm{~d}^{-1}$. Our high resolution mapping establishes a biological baseline for 3 glass sponge reefs in the Strait of Georgia.
\end{abstract}

KEY WORDS: Glass sponge reef $\cdot$ Hexactinellid sponges $\cdot$ GIS $\cdot$ ROV $\cdot$ Semivariogram

\section{INTRODUCTION}

Glass sponge reefs (Porifera, Hexactinellida) are unique habitats found on the Pacific coast of Canada where they discontinuously cover over $700 \mathrm{~km}^{2}$ of the sea floor (Conway et al. 2001, 2004). Pacific coast reefs represent a modern analogue of extinct reefs that once formed a $7000 \mathrm{~km}$ belt of sponges in the northern Tethys Sea, a region that now covers large parts of Europe (Ghiold 1991, Leinfelder et al. 1994). Today, glass sponges are generally found in deep water $(>30 \mathrm{~m})$ and often at depths greater than $300 \mathrm{~m}$ (Tabachnick 1994, Leys et al. 2007). Some 500 to 600 species of glass sponges have been described (Reiswig 2006) and fall into 2 categories based on their spicule skeleton: those with a skeleton of loose spicules termed lyssacine and those in which spicules are fused together by secondary silica deposition to form a rigid skeleton termed dictyonine (Leys et al. 2007). In
Hecate Strait 3 species of dictyonine sponges form reefs: Aphrocallistes vastus, Heterochone calyx and Farrea occa (Conway et al. 2001, Krautter et al. 2001, Whitney et al. 2005), but in the Strait of Georgia A. vastus and H. calyx are the only reef builders; Farrea occa does not occur in waters between Vancouver Island and the mainland (Leys et al. 2004).

The first modern glass sponge reefs were found at depths of 165 to $240 \mathrm{~m}$ on the continental shelf (Conway et al. 2001, Krautter et al. 2001, Whitney et al. 2005), but some have recently been documented as shallow as $30 \mathrm{~m}$ in fjords (e.g. Howe Sound, see Marliave et al. 2009). It should be noted that dense populations of glass sponges ('sponge gardens') are found throughout British Columbia fjords as described by Leys et al. (2004), but these do not generally form characteristic reef mounds in which skeletons of successive generations of sponges settle and grow on each other. Typical reefs like this gradually accumulate to reach 
heights of up to $19 \mathrm{~m}$ where the bulk of the mounds consists of dead sponges buried by sediments with only the most recent generation growing 1 to $2 \mathrm{~m}$ above the surface (Conway et al. 2001, 2005).

Glass sponges have a major ecological role in deep water habitats. In other regions of the world, dense populations of lyssacine sponges have been documented to create benthic complexity and support whole communities of other organisms (Dayton et al. 1974, Barthel 1992a,b, Bett \& Rice 1992). Also, as highly efficient feeders on ultraplankton $(<10 \mu \mathrm{m})$, the sponges assimilate large amounts of carbon and are an important link between the pelagic and benthic environments (Pile \& Young 2006, Yahel et al. 2007). Much is known about non-reef-forming hexactinellid communities in Antarctica and the Atlantic and mid-Pacific oceans, but very little about glass sponge reefs, such that even the basic patterns of distribution, abundance and growth of the sponge populations at the reefs have not yet been quantified. Due to their 3-dimensional structure, glass sponge reefs are expected to create habitat like other hexactinellid assemblages, but due to the immense area they cover the scale of their impact may be much greater.

Until now, the location of reefs has been determined using multibeam echo sounders, which provide a landscape scale (kilometres) interpretation of distribution (Conway et al. 1991, 2001, 2005, 2007). Despite the value of multibeam technology, this technique cannot differentiate between live, dead and buried portions of glass sponges within a reef. Furthermore, past linear transects and box core sampling highlighted the ecology of the reefs (Cook 2005, Cook et al. 2008, Marliave et al. 2009), but these studies quantified the community patterns of associated invertebrates and fish without first empirically establishing the extent of the live sponges, and thus interpretations may be biased. Because until now the living portions of a reef have not been measured it has not been possible to properly address questions pertaining to the biology of the reefs, their community ecology and the role glass sponge reefs have in nutrient cycling.

Therefore, the goal of our study was to use high resolution mapping techniques to determine the distribution patterns and spatial structure of live sponges at 3 reefs in the Strait of Georgia, British Columbia. The logistical challenges of working in deep water makes sampling at a small scale difficult (Grassle 1991). However, as pattern detection is scale dependent (Levin 1992, Legendre et al. 1997), we took a small scale approach by sampling at 25 and $12.5 \mathrm{~m}$ intervals within a stratified grid design using remote operated vehicles (ROV) and high resolution imagery to systematically survey the entire populations of live sponges at each reef. From observations of the patchy nature of the reefs (Conway et al. 2005), we predicted that the sponges would have a high degree of spatial structure and used semivariogram analysis and GIS to map their distributions. Dense populations of other suspension feeders have been found where elevated topography amplifies water flow (Sebens 1984, Genin et al. 1986, Barry \& Dayton 1988), and thus we predicted the distributions of glass sponges, also found on elevated mounds and ridges in the Strait of Georgia, would be strongly related to their position on the mounds. The high resolution imagery allowed us to determine patterns of association of other invertebrates and fish with the glass sponges. Finally, we used our measurements of the sponges together with previous knowledge of their filtration rates (Yahel et al. 2007) to estimate the effect sponge reefs have on bentho-pelagic coupling of nutrients.

\section{MATERIALS AND METHODS}

Reef sites. The Strait of Georgia (SOG, Fig. 1 inset) is approximately $28 \mathrm{~km}$ wide by $222 \mathrm{~km}$ long with an average depth of $155 \mathrm{~m}$ and separates the British Columbia mainland from Vancouver Island on the Pacific coast of Canada (Thomson 1981). Glass sponge reefs in the SOG are only found on undifferentiated bedrock features elevated from the fine-grained depositional sediments comprising the majority of the seafloor in the SOG basin. The 3 reefs in this study are referred to by names reflecting their proximity to local geographic features (Fig. 1 \& Fig. S1 in Supplement 1, available at: www.int-res.com/articles/suppl/m417p097_ supp.pdf).

Howe Sound reefs: Howe Sound (49 $19^{\circ} 57.672^{\prime \prime} \mathrm{N}$, $123^{\circ} 17^{\prime} 42.297^{\prime \prime} \mathrm{W}$ ) is a fjord located northwest of the city of Vancouver. High freshwater discharge carrying fine silts from the nearby Squamish River, Cheakamus River and the Fraser River plume are characteristic of the surface waters flowing over this area (Burd et al. 2008). The glass sponge reefs here exist in several discontinuous patches on sloped bathymetry outside of the mouth of Howe Sound. One reef was surveyed at the mouth of Howe Sound (hereafter referred to as Howe reef). Marliave et al. (2009) described the associated animal community from ROV videotapes of a $\sim 200 \mathrm{~m}$ transect running diagonally through this reef.

Fraser Ridge reefs: The Fraser Ridge $\left(49^{\circ} 9^{\prime} 15.673^{\prime \prime} \mathrm{N}\right.$, $123^{\circ} 23^{\prime} 3.705^{\prime \prime} \mathrm{W}$ ) is an elevated mound capped by glacial sediments (Conway et al. 2004) that lies slightly offshore in the path of the Fraser River outflow (Conway et al. 2005). The surface waters here experience high sedimentation rates as the Fraser River is the source of $80 \%$ of the sediments in the SOG (Hill et al. 2008). The glass sponge reefs (hereafter referred to as 


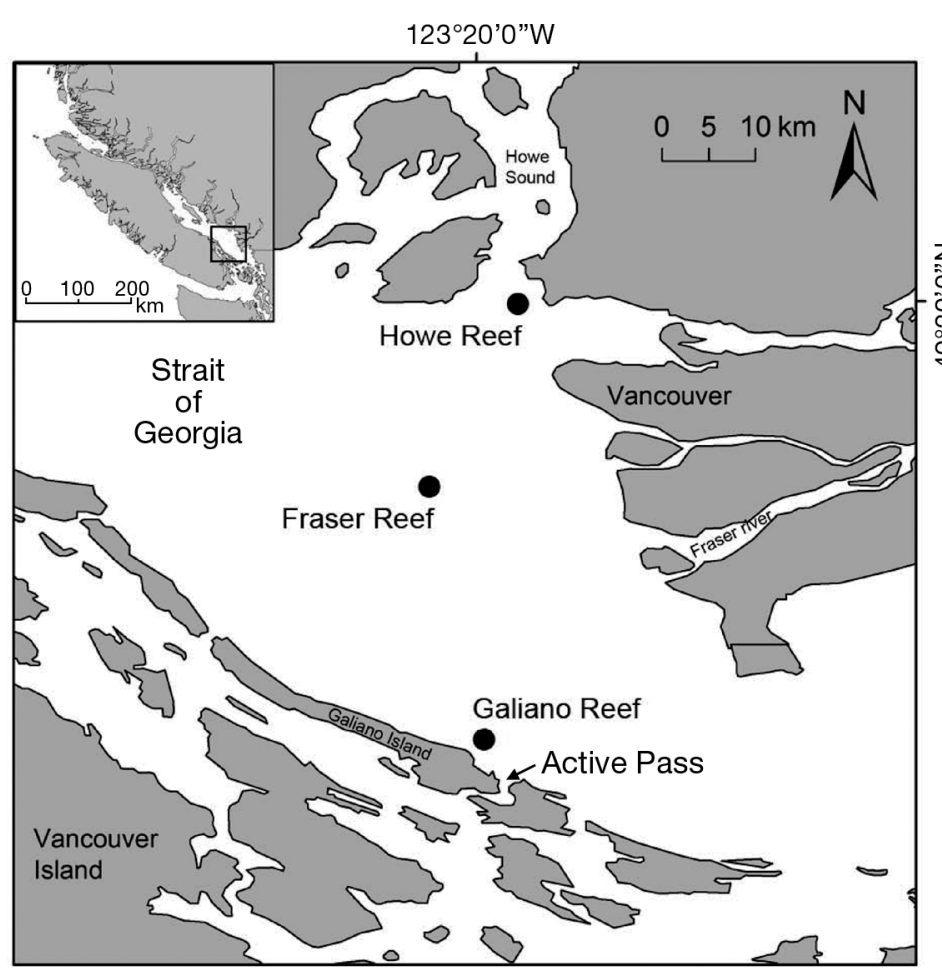

Fig. 1. Locations of the Howe, Fraser and Galiano glass sponge reefs within the Strait of Georgia. Inset shows relative location of study sites in the strait between Vancouver Island and mainland British Columbia, Canada

Fraser reef) occur in several small patches on the northeast and west sides of the mound (Conway et al. 2004).

Galiano Ridge reefs: The Galiano Ridge $\left(48^{\circ} 54^{\prime} 51.468^{\prime \prime} \mathrm{N}, 123^{\circ} 19^{\prime} 27.654^{\prime \prime} \mathrm{W}\right)$ is a continuous submarine crest that runs linearly in a northwestsoutheast direction for over $40 \mathrm{~km}$ parallel to the eastern shoreline of Galiano Island in the Strait of Georgia. The ridge is a crustal fold created at the tectonic forearc from the subduction zone of the Juan de Fuca plate moving under the North American landmass (Hill et al. 2008). The glass sponge reefs here are found in discontinuous patches along an approximate 5 to $6 \mathrm{~km}$ stretch north and south of Active Pass (Conway et al. 2007). A $1.5 \mathrm{~km}$ section north of Active Pass was surveyed (hereafter referred to as Galiano reef).

ROV field sampling. Quantified field surveys were carried out during 3 scientific cruises (ROPOS in 2007, Phantom in 2008 and ROPOS in 2009). To establish a replicable sampling protocol, a pilot survey was carried out at Fraser Ridge in 2005 with the Canadian operated ROV ROPOS. To maximize the logistical trade-offs of small-scale sampling relative to the large benthic area covered by a reef, we used a sampling grid of $25 \mathrm{~m}$ established during the pilot survey. A perimeter was created around all the sponges during this pilot survey and a georeferenced $25 \mathrm{~m}$ stratified grid of points $(\mathrm{n}=300)$ was overlaid within this perimeter for our quantified sampling in 2009 (Fig. 2A). For Howe and Galiano reefs a $25 \mathrm{~m}$ grid of points ( $\mathrm{n}=309$ and $\mathrm{n}=238$, respectively) was determined by delineating the reef perimeter from multibeam bathymetry mapped by the Canadian Hydrographic Service in 2007 (Fig. 2B,C) with a priori knowledge (K. Conway, National Research Council Canada, pers. comm.) and modified during the survey.

During each survey ROPOS 'flew' to each point in the grid, hovered 1 to $2 \mathrm{~m}$ above the benthos and captured an image with a downward-looking digital still camera (DSC, Sony Cyber-Shot DSC F707). A Phantom HD2+2 ROV (Deep Ocean Engineering) operated by the Pacific Biological Station (Nanaimo, British Columbia) and equipped with a DSC (Olympus SP350) with slaved strobe (TTL capable Ikelite 200) was also used to survey a different area at Galiano reef. The 2 ROV platforms had different size, power and hardware configurations and current-induced drag on the ROV tether prevented the Phantom from remaining stationary at predetermined points. Instead of a stratified grid design the Phantom flew $25 \mathrm{~m}$ spaced transect lines running northwest of the ROPOS waypoints created in 2007 (Fig. 2C) and captured 1 image approximately every $20 \mathrm{~s}(\mathrm{n}=515)$ while flying approximately $1 \mathrm{~m}$ above the benthos. The slaved strobe allowed sharp images to be taken while the Phantom was in motion. Each ROPOS image was 5 megapixels (MP) and covered approximately $3.2 \mathrm{~m}^{2}$ of substrate. Each Phantom image was $8 \mathrm{MP}$ and covered $1.2 \mathrm{~m}^{2}$ of substrate. Images from both ROV platforms had $10 \mathrm{~cm}$ laser dots for scale.

Fine scale survey: Preliminary analysis of data from the $25 \mathrm{~m}$ grid survey at Galiano reef in 2007 suggested spatial patterns occur at a scale less than $25 \mathrm{~m}$. Therefore in 2009, we subdivided the original $25 \mathrm{~m}$ grid with additional waypoints to sample an area of high sponge density in a $12.5 \mathrm{~m}$ grid (Fig. 2D).

Image analysis of glass sponges and reef biota. The area of each image was measured in Adobe Photoshop CS3 with the image analysis tool. Areas of live sponge, dead sponge and bare substrate (mud or exposed bedrock) were delineated and converted into percentage of cover data. Only ROPOS 2009 images were used to compare sponge morphology among reefs. Because the osculum (the excurrent vent of the sponge) determines the volume of water the sponge processes (assuming fixed velocity pumping), the number of oscula was used as an indicator of the density of live sponges and therefore the robustness of a reef. All dictyonine sponge oscula were counted and the area of 

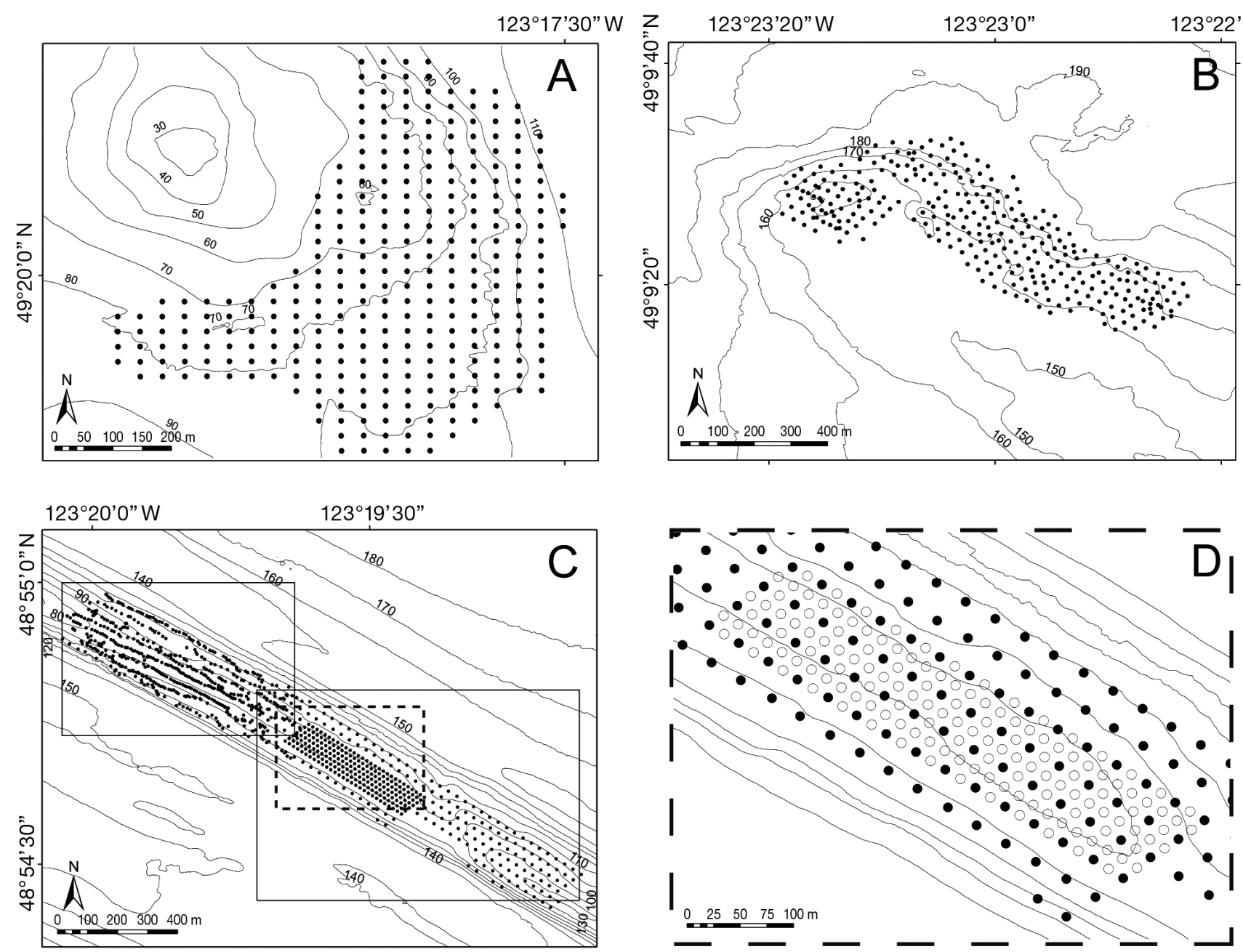

Fig. 2. Schematic of the field sampling designs at each of the reefs. A downward-facing digital image was taken at every point along a stratified $25 \mathrm{~m}$ survey grid with ROPOS. (A) Howe $(n=309)$, (B) Fraser $(n=300)$, (C,D) Galiano. In $(C)$, the solid boxes indicate the area covered by the $25 \mathrm{~m}$ stratified grid surveyed with ROPOS in $2007(\mathrm{n}=238$ ) and the transect line points surveyed with the Phantom $2008(\mathrm{n}=515)$. The dashed line indicates the area sampled at a finer scale. In (D), additional points sampled by ROPOS in $2009(\mathrm{n}=143)$ are represented by open circles $(O)$; these subdivided the original $25 \mathrm{~m}$ grid points represented by solid circles ( ) into a $12.5 \mathrm{~m}$ grid. Depth contour lines are shown in $10 \mathrm{~m}$ intervals

those facing directly into the camera was measured. The size distributions of oscula at each reef, their mean area, SD and coefficient of variation $(\mathrm{CV})$ were calculated for each reef. Aphrocallistes vastus and Heterochone calyx are morphologically similar in the reefs, and because we could not perform extensive sampling for species confirmation we were unable to differentiate between the 2 closely related dictyonine species using only our survey images, and therefore refer to them as dictyonine sponges in our interpretations where appropriate.

Instead of counting individual sponges, individual oscula, as single pumping (water processing) units, were counted, because it was not possible to identify individuals in the mass of oscula arising from the reef. The number of live oscula in the area surveyed and the number of live oscula in a continuous patch of live sponge were standardized to obtain density per $\mathrm{m}^{2}$. Only images covering areas $>1 \mathrm{~m}^{2}$ were used to prevent extrapolation of oscula density measurements; from each reef 78 images were analyzed for density over the substrate, and 10 images were chosen at random from each reef and analyzed for density per live sponge cover.

Animals $>4 \mathrm{~cm}$ in length were identified to the lowest taxonomic level possible from the ROPOS 2009 dives and the Phantom 2008 dives. Abundance data could not be pooled across ROV platforms because of the differences in area sampled and the increased resolution of the Phantom camera.

Multivariate and univariate analyses were used to compare differences in the community composition and abundances of animals in a reef. Using only ROPOS 2009 images, a matrix was created on log- 
transformed abundance data using the Bray-Curtis similarity index. Then analysis of similarity (ANOSIM) tests were used to determine differences in the community composition and analysis of variance ANOVA was used to determine differences in total animal abundance between the 3 reefs. Similarly, using only Phantom 2008 images, the differences in the community composition and the abundance of individual taxa (Porifera, Cnidaria, Annelida, Mollusca, Arthropoda, Echinodermata and fishes) were determined between areas with and without glass sponges. Counts of unidentifiable fish, large blurred schools (>30 individuals) and highly mobile fish species (e.g. ratfish) were not included in the analyses to avoid counting individuals more than once. All multivariate analyses were done with PRIMER v. 5.2.2 and all univariate analyses were done with JMP v. 7.0

Spatial analyses of glass sponge distributions. Patchy distributions are ideally suited for semivariogram analysis, which can determine the maximum distance 2 points are spatially autocorrelated in an area (Robertson et al. 1988, Rossi et al. 1992). If spatial autocorrelation exists, the semivariogram model parameters can then be used to interpolate the unsampled regions between points to create a continuous surface, in this case, the sponge cover across the entire area surveyed. Spatial universal transverse mercator (UTM) coordinates (metres) and values of percent live sponge cover were used as the $x-y-z$ data for creating our experimental semivariogram models. Spherical models best explained the data based on the proportion of variance resolved by the spatial structure $\left(\mathrm{C} / \mathrm{C}_{0}+\mathrm{C}\right)$, the coefficient of determination $\left(\mathrm{r}^{2}\right)$ and the residual sum of squares (RSS). Estimated parameters were the nugget effect $\left(\mathrm{C}_{0}\right)$, which captures variation at distances less than our minimum sampling distance between points, the sill $\left(\mathrm{C}_{0}+\mathrm{C}\right)$, which indicates where the semivariance asymptotes or the overall variance of the sponge cover, and the range $\left(\mathrm{A}_{0}\right)$, which defines the maximum distance at which spatial autocorrelation exists. Points separated at distances greater than the range were considered spatially independent. All semivariogram analyses were performed in GS+ v. 3.1.7.

Visual estimates of live sponge cover were made during each dive in 2009 and preliminary isopleths were interpolated directly onboard the ship to create rough maps of sponge distributions. These maps were used to sample live sponges for other research objectives and allowed us to ground-truth the semivariogram models. Since spatial autocorrelation existed in all the surveys, percent live sponge cover (from precise area measurements in each image) was interpolated into $5 \%$ isopleth intervals by kriging. In ArcView 9.2 a layer mask polygon was created using the outer grid points as the perimeter to prevent interpolation outside the surveyed area. The proportional area covered by all isopleth levels was summed to estimate the total area of live and dead sponge cover. All maps are displayed in projection GCS WGS 1984 and all spatial analyses were done in projection WGS 1984 Complex UTM Zone 10N.

For analysis of the relationship between live sponge cover and depth and slope, we only used images that were separated by a distance greater than the range distance revealed from each reef's semivariogram model. A slope (incline in degrees) raster layer was created from the high resolution (5 $\mathrm{m}$ cell) multibeam bathymetry data using the spatial analysis tool in ArcView v. 9.2. Each of our survey points was then intersected with the depth and slope layers with the Hawth's Analysis Tools extension (Beyer 2004). The extent to which percent cover of live sponges was correlated with dead sponges, depth and slope was analyzed with Spearman rank correlation coefficients. Bathymetry data was provided by the Canadian Hydrographic Service in cooperation with the Geological Survey of Canada (Barrie et al. 2005).

\section{RESULTS}

\section{Live sponge distribution at each reef}

Relative to the total area surveyed at each reef, Howe reef had the least live sponge cover $(11.6 \%$ of the benthos covered with sponges); live sponge cover at Fraser reef was also low (14.5\%), while Galiano reef had the highest relative live sponge cover (26\%) (Table 1). The distribution of sponges was confirmed to be patchy because the distribution of live sponges was spatially autocorrelated at all reefs. Within reefs, our spherical models resolved 75 to $80 \%$ of the structural variance and revealed range distances of 42, 58 and

Table 1. Estimates of sponge cover. The total survey area includes the area enclosed by the grid of points in each reef survey (see Fig. 2). The proportion of area covered by all (live and dead) sponges relative to the total sponge reef area is given in parentheses. The proportion of the area covered in our surveys that is reef is indicated by 'proportion'. Areas without sponge cover were bare substrate consisting of patches of mud or exposed bedrock

\begin{tabular}{|c|c|c|c|c|c|}
\hline \multirow[t]{2}{*}{ Reef } & \multirow{2}{*}{$\begin{array}{c}\text { Total survey } \\
\text { area }\left(\mathrm{m}^{2}\right)\end{array}$} & \multicolumn{3}{|c|}{ Area of sponge reef $\left(\mathrm{m}^{2}\right)$} & \multirow{2}{*}{$\begin{array}{c}\text { Proportion } \\
\text { (\%) }\end{array}$} \\
\hline & & Live & Dead & Total & \\
\hline Howe & 166500 & $10242(53.0 \%)$ & $9083(47.0 \%)$ & 19325 & 11.6 \\
\hline Frase & 142775 & $13774(66.5 \%)$ & 6945 (33.5\%) & 20720 & 14.5 \\
\hline Galiano & 208250 & $23432(44.0 \%)$ & $29799(56.0 \%)$ & 53231 & 26.0 \\
\hline
\end{tabular}


$72 \mathrm{~m}$ for Fraser, Howe and Galiano reefs, respectively, at a $25 \mathrm{~m}$ sampling resolution (Table 2, Fig. 3). At Galiano reef, the semivariogram of our $12.5 \mathrm{~m}$ finescale survey showed that sponge patches were correlated at half that distance, with a range distance of $35 \mathrm{~m}$, even though a similar proportion of the structural variance $(78 \%)$ was resolved by both surveys. At all reefs, points were uncorrelated beyond these distances based on the clear horizontal sill found in all semivari- ograms (Fig. 3). All semivariograms had a nugget variance $\left(\mathrm{C}_{0}\right)$ between 27 and $34 \%$ of the structural variance (C), which indicates spatial structure occurs at scales less than our minimum sampling distances of 25 and $12.5 \mathrm{~m}$ (Table 2).

Kriging at $5 \%$ sponge cover intervals revealed where the densest concentrations of live sponges were located at each reef. At Howe reef, live sponge cover occurred in sparse patches with most areas showing $<20 \%$ cover and a few areas showing $>50 \%$ cover (Fig. 4). The substrate in between the sparse patches consisted of large expanses of fine silt-clay sediments. At Howe reef the area of live sponge cover was smaller than that identified by the multibeam data (Fig. 4). At Fraser reef, patches of live sponges occurred in hotspots with 4 nodes of $>80 \%$ cover (Fig. 4), and large expanses of mud were less common. At Galiano reef, live sponges formed multiple hotspots in concentric patterns along the crest. Seven
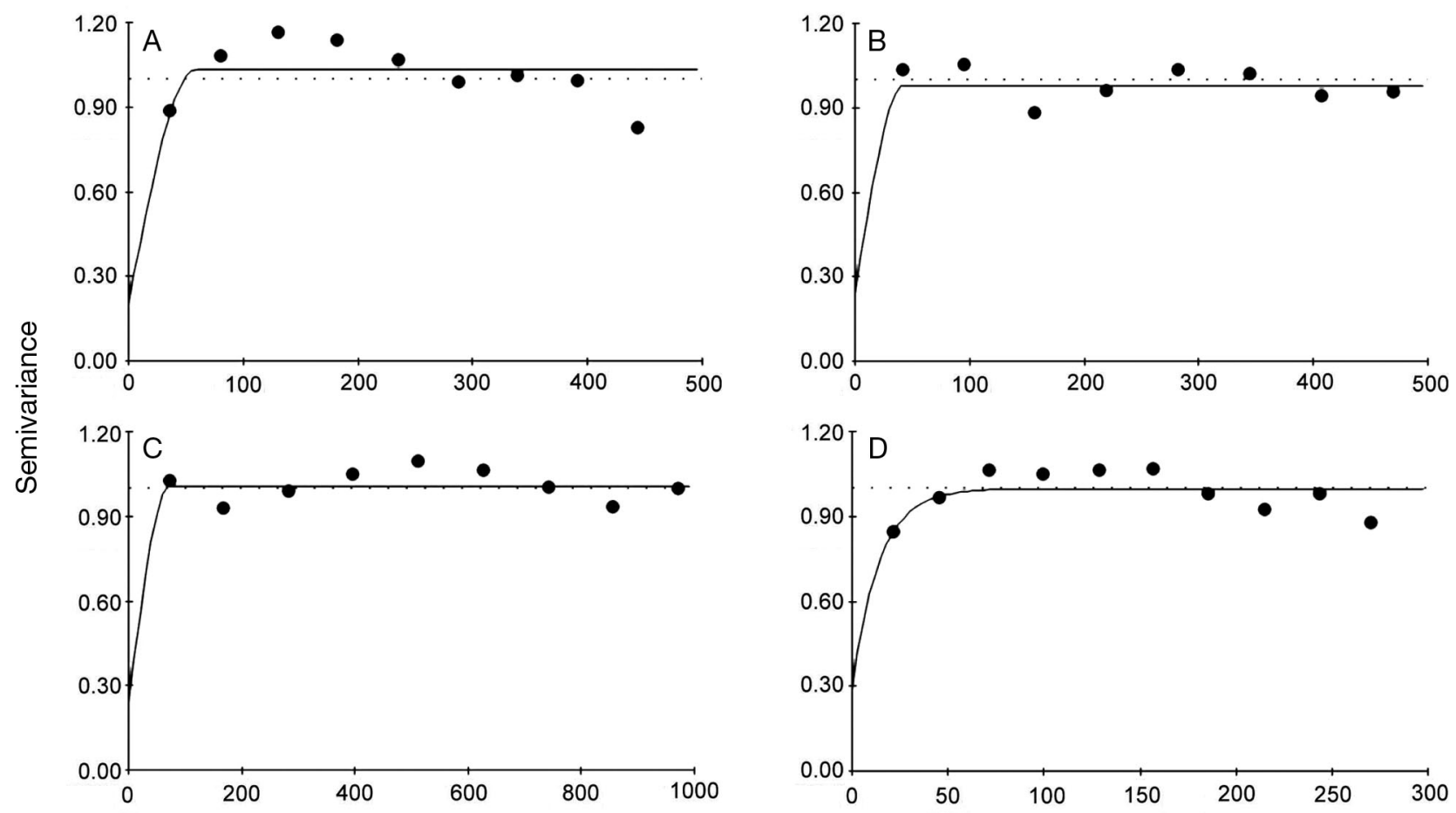

Distance $(m)$

Fig. 3. Experimental semivariograms showing spatial structure of sponges within each survey area (created from the model parameters in Table 4). (A) Howe Sound $25 \mathrm{~m}$ grid sampling. (B) Fraser Ridge $25 \mathrm{~m}$ grid sampling. (C) Galiano Ridge $25 \mathrm{~m}$ grid and Phantom transect lines sampling. (D) Galiano Ridge $12.5 \mathrm{~m}$ grid sampling. Each semivariogram represents the entire spatial structure within the survey area of the respective reef (see Fig. 2). Dots represent lag distance intervals for each reef survey. Spatial autocorrelation occurred at each reef up to the range distance signified by the sill (dotted line) of each semivariogram. Note the different scales on the $x$-axis are a result of the different dimensions of the area covered in each survey 
A
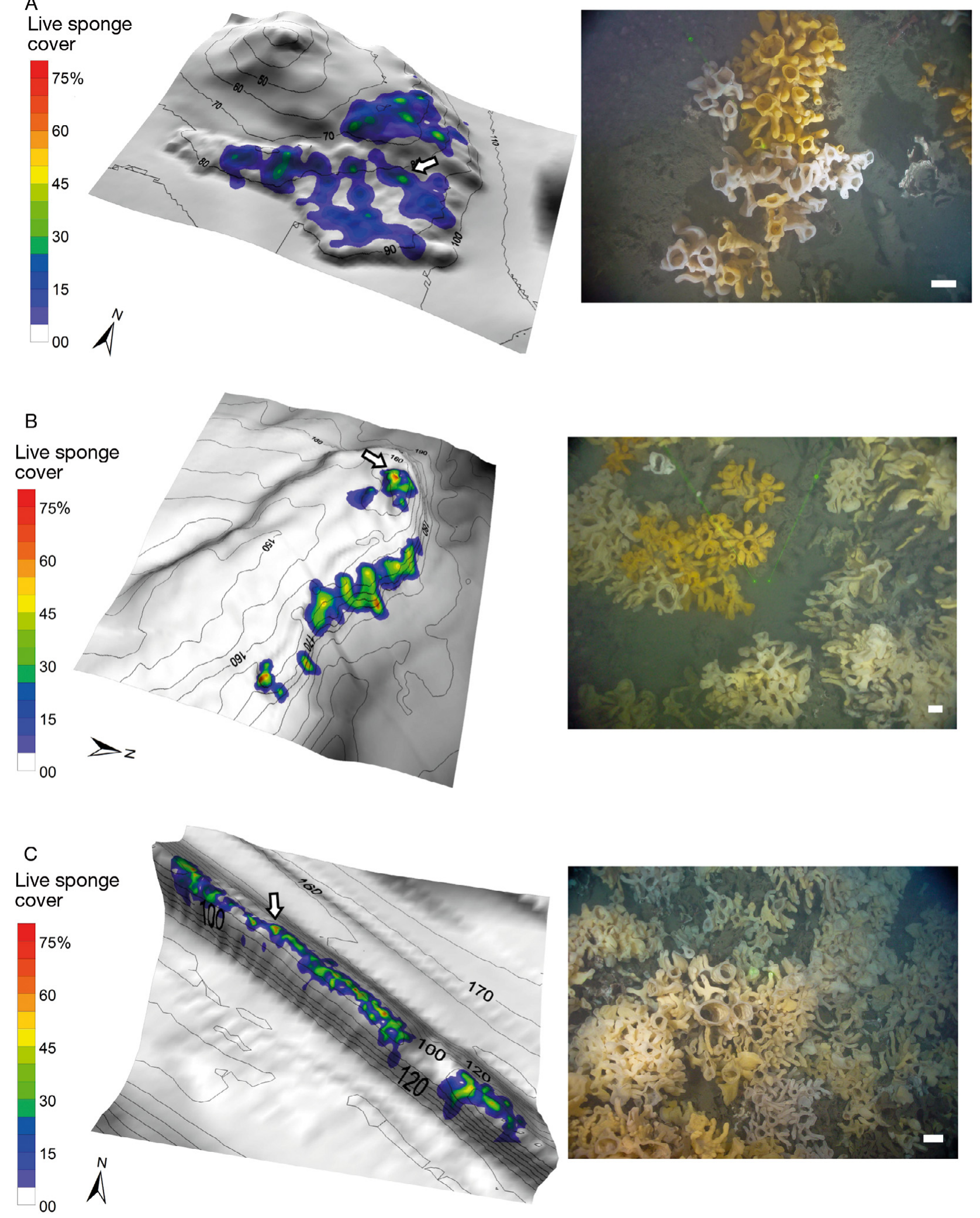

Fig. 4. Distribution maps and images of live glass sponges at each reef. (A) Howe, (B) Fraser, (C) Galiano. Areas were interpolated by kriging using semivariogram parameters of Table 4. At Howe reef our survey of live sponge cover is shown as an overlay on top of the bathymetry mapped with multibeam in 2007. Isopleths of live sponge cover are plotted in $5 \%$ increments. Note north is different for each reef. Images from each reef correspond to white arrows on their respective kriging maps. Scale bars in images are $10 \mathrm{~cm}$ 
nodes had $>80 \%$ live sponge cover and several smaller regions had over $50 \%$ coverage of live sponges (Galiano, Fig. 4); there were few mud patches in the area we surveyed at Galiano reef. Fine-scale sampling $(12.5 \mathrm{~m})$ at Galiano reef showed that the sponges were on either side of the ridge top as the percent live cover increased with increasing slope down from the crest (Fig. 5A,B).

At all 3 reefs, the live glass sponges were confined to a narrow range of depths $(<50 \mathrm{~m})$ but were on a wide range of slopes $\left(1\right.$ to $52^{\circ}$ ). At Howe and Fraser reefs, live sponges were found on one side of the underlying mounds; the majority of sponges at Galiano reef were found on both sides of the ridge slopes (Table 3). At all reefs live sponge cover was positively correlated with dead sponge cover. Most sponges were found at the crest, the shallowest portion of the bathymetry we surveyed, and therefore were negatively correlated with depth. Despite predominantly being found on sloped topography, live sponge cover was not correlated with slope angle at any of the reefs (Table 3).

\section{Density and size of sponge oscula at each reef}

Most dictyonine sponges in the reefs formed tightly clustered bushes of tubes, each with an osculum growing up to $1 \mathrm{~m}$ above the substrate. At Galiano reef, we saw small sponges $(<10 \mathrm{~cm}$ oscula diameter) with fine branches extending from the base to form additional oscula (Fig. 6A). We interpreted growth to occur by this process because groups of oscula were all fused to a single base (Fig. 6B). Larger bushes with oscula facing many directions (Fig. 6C) may therefore arise from multiple branching events, as shown by the single basal attachment point on a dead sponge bush in Fig. 6D.

The density of sponge oscula (counts of oscula $\mathrm{m}^{-2}$ surveyed) was significantly different between reefs (Kruskall-Wallis: $\mathrm{p}<0.0001$ ). Galiano reef had the highest density at 17.4 oscula $\mathrm{m}^{-2}$, Fraser reef had 9.4 oscula $\mathrm{m}^{-2}$ and Howe reef had 5.5 oscula $\mathrm{m}^{-2}$ (Fig. 7A). Within continuous patches of live sponge, the
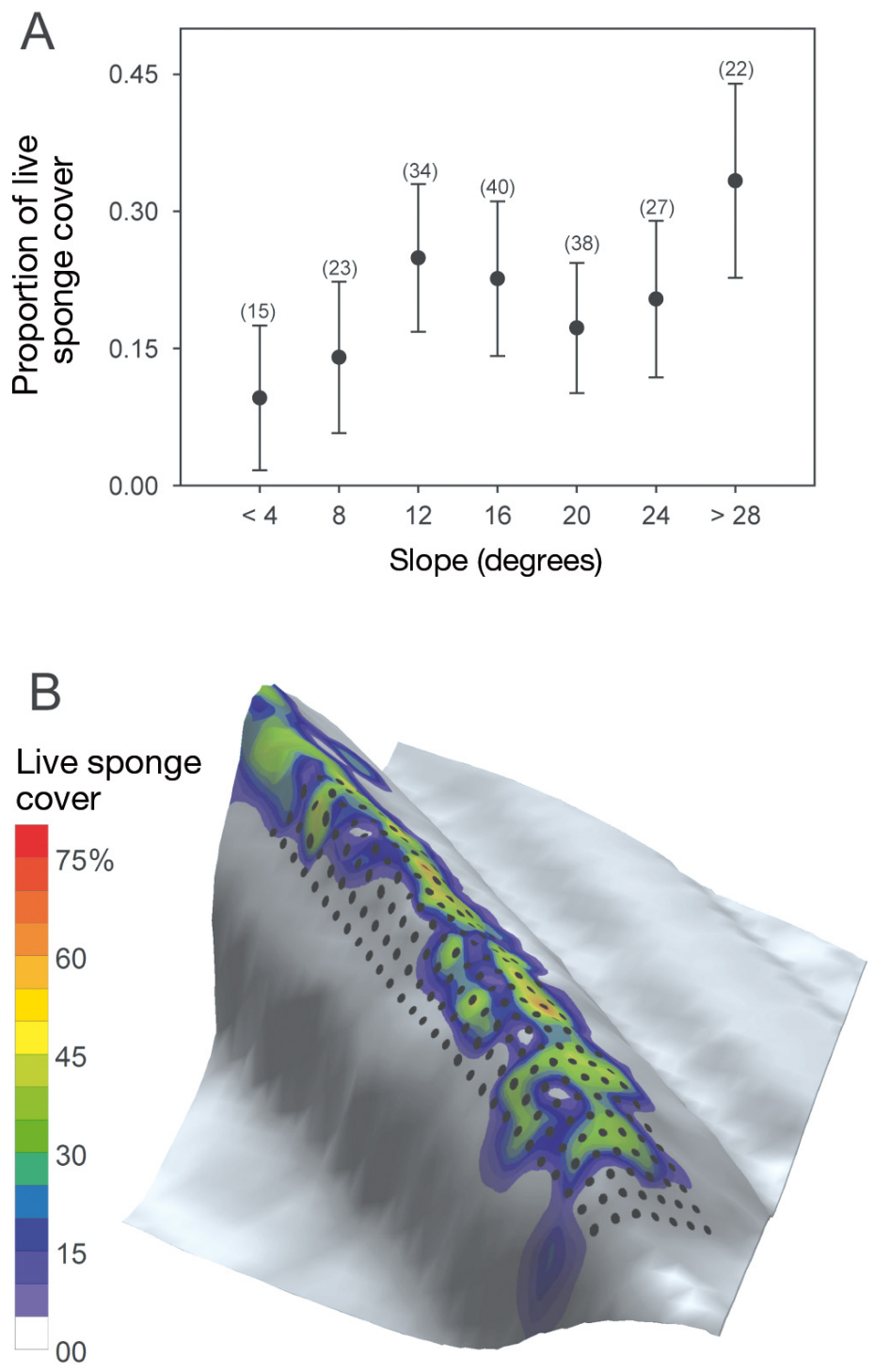

Fig. 5. Distribution of sponges at Galiano reef. (A) The percentage of live sponge cover was greater at slope angles $\geq 12^{\circ}$ within the $12.5 \mathrm{~m}$ grid survey area. The percent live cover was averaged from slope classes at $4^{\circ}$ intervals. Sample sizes are shown in parentheses, error bars indicate 95\% CI (B) The down-slope sponge distributions can be seen in the kriging results of the $12.5 \mathrm{~m}$ grid

Table 3. General characteristics of the distributions of live glass sponges at each reef. Depth (m) and slope (degrees) are reported as mean $( \pm \mathrm{SD})$ and range. 'Survey' refers to the 'total' set of waypoints (see Fig. 2) where images were taken and 'sponges present' indicates the number of images in which glass sponges were present. Spearman rank correlation coefficients $\left(\mathrm{r}_{\mathrm{s}}\right)$ are provided for each reef; live sponge cover $(\%)$ was correlated to dead sponge cover, depth and slope $\left({ }^{*} \mathrm{p}<0.05 ;{ }^{* *} \mathrm{p}<0.0001\right.$; ns: not significant, $\mathrm{p}>0.05$ )

\begin{tabular}{|c|c|c|c|c|c|c|c|c|c|}
\hline \multirow{2}{*}{ Reef } & \multirow{2}{*}{$\overline{\text { Total }}$} & \multirow{2}{*}{$\begin{array}{c}\text { Survey } \\
\text { Sponges } \\
\text { present }\end{array}$} & \multicolumn{2}{|c|}{ Depth $\longrightarrow$} & \multicolumn{2}{|c|}{- Slope -} & \multicolumn{3}{|c|}{ Spearman rank correlations $\left(\mathrm{r}_{\mathrm{s}}\right)$} \\
\hline & & & Mean & Range & Mean & Range & $\begin{array}{c}\text { Dead } \\
\text { sponge }\end{array}$ & Depth & Slope \\
\hline Howe & 309 & 133 & $79 \pm 9$ & $59-102$ & $11 \pm 6$ & $1-30$ & $0.770^{* *}$ & $-0.422^{* *}$ & $-0.027 \mathrm{~ns}$ \\
\hline Fraser & 300 & 84 & $162 \pm 9$ & $147-180$ & $10 \pm 7$ & $1-35$ & $0.730^{* *}$ & $-0.180^{*}$ & $-0.123 \mathrm{~ns}$ \\
\hline Galiano & 896 & 497 & $90 \pm 8$ & $69-119$ & $16 \pm 8$ & $1-52$ & $0.689^{* *}$ & $-0.532^{* *}$ & $-0.244 \mathrm{~ns}$ \\
\hline
\end{tabular}



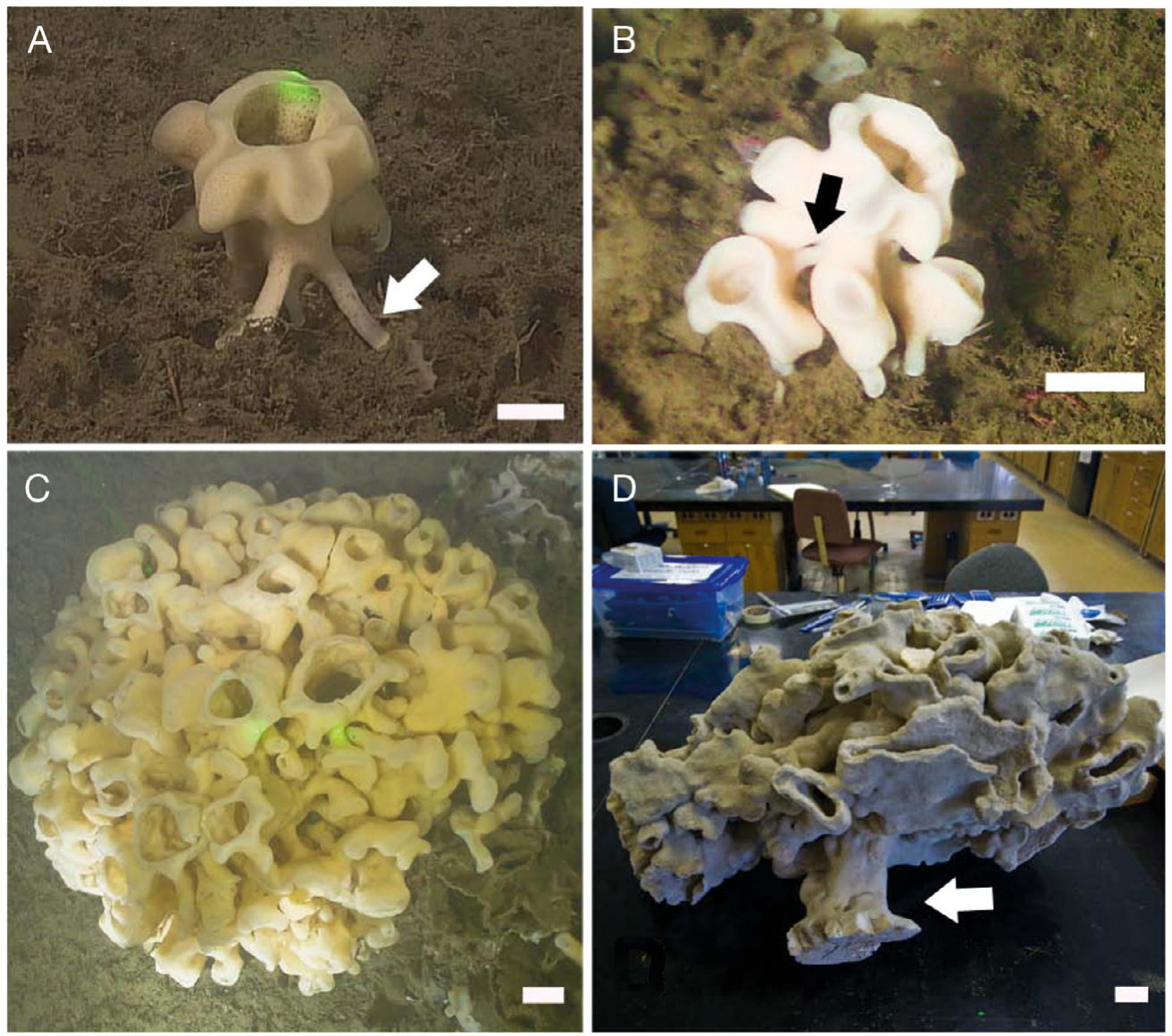

Fig. 6. Asexual budding and bush formation observed in dictyonine sponges. (A) A dictyonine sponge at Galiano reef with an extension budding from the base. (B) New oscula form at tips of extensions. (C) Continuous budding forms a characteristic bush of Aphrocallistes vastus with densely packed oscula. (D) A dead A. vastus bush illustrates the single basal attachment point that supports the entire individual. Scale bars are $5 \mathrm{~cm}$

density of sponge oscula was also significantly greater at Galiano reef $\left(46.3\right.$ oscula $\mathrm{m}^{-2}$ ) than at Howe reef (30.9 oscula $\mathrm{m}^{-2}$ ) or Fraser reef $\left(23.0\right.$ oscula $\mathrm{m}^{-2}$ ) (Fig. 7B; Kruskall-Wallis: $\mathrm{p}<0.0001$ ). However, even though there were fewer oscula at Fraser reef, the average size of oscula at Fraser reef was significantly larger $\left(38.3 \mathrm{~cm}^{2}\right)$ than at either Galiano $\left(23.0 \mathrm{~cm}^{2}\right)$ or Howe $\left(12.8 \mathrm{~cm}^{2}\right)$ reefs (Fig. $7 \mathrm{C}_{i}$ Kruskal-Wallis: $\left.\mathrm{p}<0.0001\right)$.

At all reefs, the size of oscula was highly variable but was nevertheless positively skewed towards smaller class sizes (Fig. 8). Log-transformed size data normalized distributions of the size classes at Howe reef and Galiano reef, but not at Fraser reef because of the greater number of individuals with large oscula. The proportion of sponges with small oscula $\left(<5 \mathrm{~cm}^{2}\right)$ was greatest at Howe reef $(28 \%)$ compared with Galiano reef $(19 \%)$ and Fraser reef $(11 \%)$. The converse was also found: Howe reef had the fewest sponges with oscula $\geq 100 \mathrm{~cm}^{2}(1 \%)$ compared with Galiano reef $(3 \%)$ and Fraser reef $(9 \%)$.

\section{Animals associated with glass sponges in the reefs}

We identified a diverse assemblage of animals living on and among dictyonine sponges representing 7 phyla and 14 classes from our Phantom 2008 and ROPOS 2009 survey images (Table 4 ; see video in Supplement 2 at www.int-res.com/articles/suppl/m417p097_supp/). The community composition was significantly different between all 3 reefs (Table 5; ANOSIM: R $=0.153$, $p<$ 0.001). The differences between communities were mainly driven by the greater abundance of the squat lobster Munida quadraspina, spot prawn Pandalus platyceros and rockfish Sebastes spp. at Galiano reef, greater abundance of the demosponge Tetilla sp. at Fraser reef, and greater abundance of the sea whip Halipteris willeomoesi among the sponges at Howe reef. In general, significantly more animals were found at Galiano reef than at either Fraser or Howe reefs (Fig. 9; Kruskall-Wallis: $\mathrm{p}<0.0001$ ). At Galiano reef, the total abundance of animals was significantly greater in 
the presence of reef sponges than in areas of bare substrate (Fig. 10; Mann-Whitney $U$-test: $\mathrm{p}<0.0001$ ).

The community composition was also significantly different in the presence of glass sponges compared with areas of bare substrate (Table 5; ANOSIM: $\mathrm{R}=$ $0.246, \mathrm{p}<0.0001)$. The main driver of this difference was the greater abundance of Munida quadraspina in the presence of glass sponges. However, when we examined the abundance within each phyla, there were significantly more crustaceans and fish found in the presence of reef sponges (Fig. 10; separate MannWhitney $U$-tests: $\mathrm{p}<0.0001)$ with significantly fewer
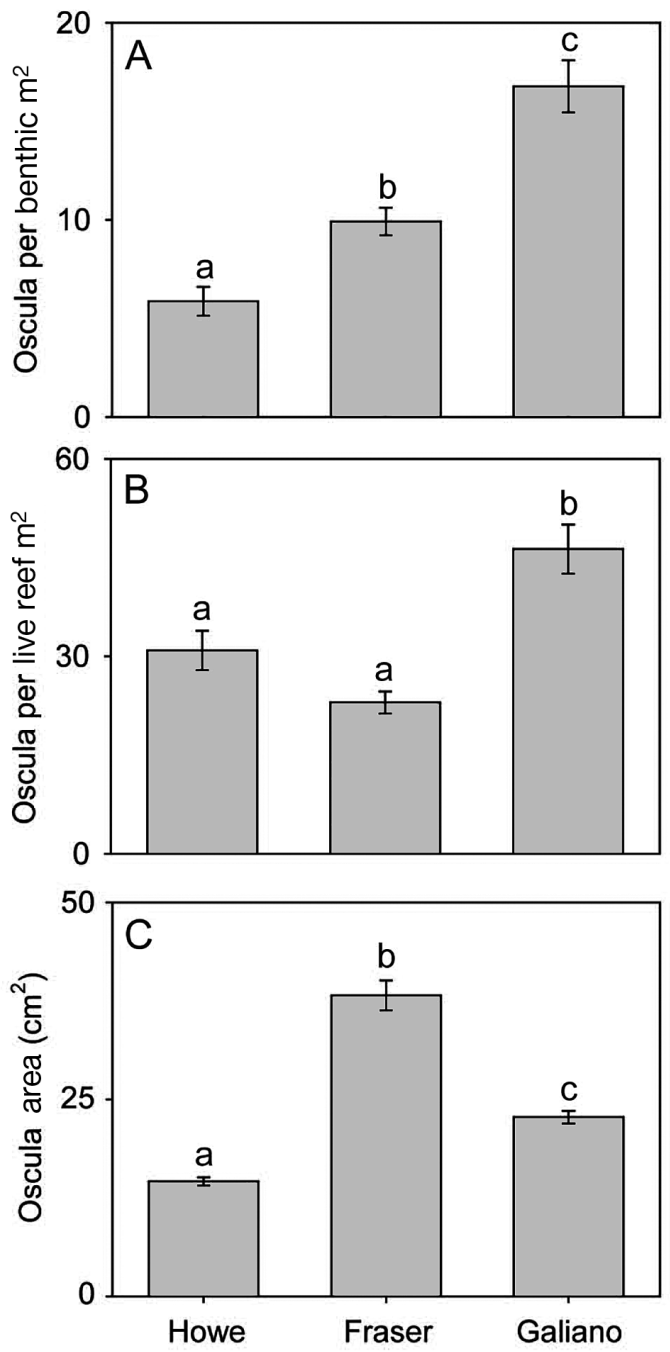

Fig. 7. Comparison of the area and densities of oscula between reefs. (A) Density of sponge oscula relative to benthic area surveyed; graphs show means from 78 images chosen randomly from all captured. (B) Density of oscula in a continuous patch of live sponges; graphs show means from 10 images chosen randomly from all captured. (C) Sponge oscula area among reefs; graphed values show means from 600 random oscula. Error bars are $\pm 1 \mathrm{SE}$. Different letters above columns indicate a significant difference from others $(p<0.0001)$ other sponges (Fig. 10; Mann-Whitney $U$-test: p < 0.0001) and molluscs (Fig. 10; Mann-Whitney $U$-test: $\mathrm{p}<0.05$ ) in the presence of reef sponges. There was no detectable difference in the abundance of cnidarians, echinoderms and annelids in the presence or absence of reef sponges (Fig. 10; separate Mann-Whitney $U$-tests: $\mathrm{p}>0.05$ ).
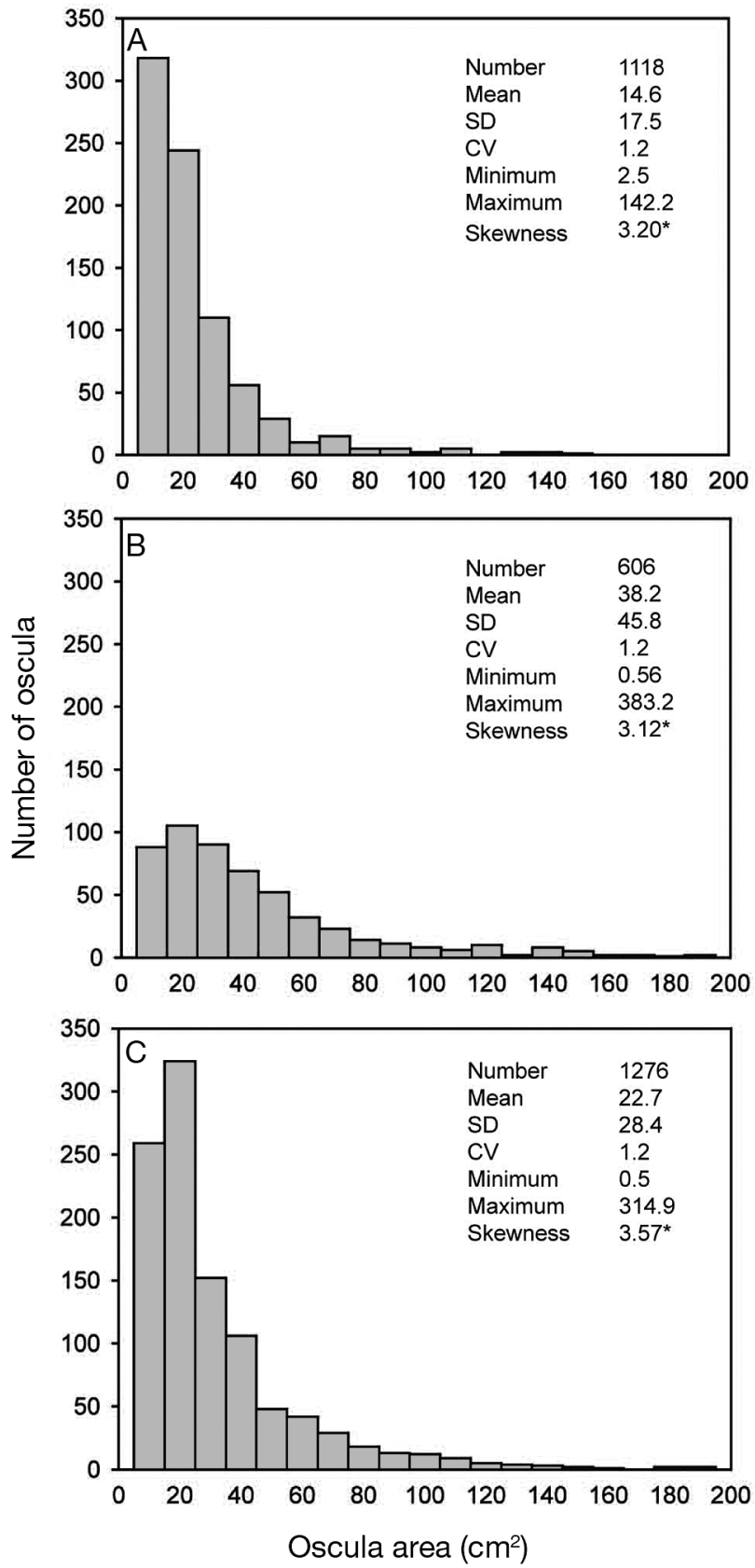

Fig. 8. Size frequency histograms and summary statistics of glass sponge oscula (Aphrocallistes vastus and Heterochone Calyx) at the (A) Howe, (B) Fraser and (C) Galiano reefs. Asterisk $\left({ }^{*}\right)$ indicates the distributions of oscula size classes were significantly skewed from 600 randomly chosen oscula (Shapiro-Wilks test: $\mathrm{p}<0.0001$ in all cases) 
Table 4. Animals living on and within close proximity to dictyonine sponges counted in images from surveys at Galiano reef in 2008 (Phantom 2008) and among all 3 reefs (ROPOS 2009). Identifications were made to lowest possible taxonomic level (taxon). Total counts are shown from Phantom 2008 images (Galiano) and ROPOS 2009 images (pooled across reefs). na: not available

\begin{tabular}{|c|c|c|c|}
\hline $\begin{array}{r}\text { Phylum } \\
\text { Class }\end{array}$ & Taxon & $\begin{array}{c}\text { Phantom } \\
2008\end{array}$ & $\begin{array}{c}\text { ROPOS } \\
2009\end{array}$ \\
\hline \multicolumn{4}{|l|}{ Porifera } \\
\hline Hexactinellida & Rhabdocalyptus dawsoni & 31 & 3 \\
\hline \multirow[t]{5}{*}{ Demospongiae } & Desmacella austini $^{\mathrm{a}}$ & na & na \\
\hline & Iophon sp. & 13 & 13 \\
\hline & Poecillastra sp. & & 2 \\
\hline & Stylissa sp. & 110 & \\
\hline & Tetilla sp. & 17 & 65 \\
\hline \multicolumn{4}{|l|}{ Cnidaria } \\
\hline \multirow[t]{4}{*}{ Anthozoa } & Cribrinopsis fernaldi & 7 & 8 \\
\hline & Halipteris willeomoesi & & 118 \\
\hline & Metridium farimen & & 1 \\
\hline & Order: Actiniaria & 2 & \\
\hline Hydrozoa & Unidentified species & 3 & \\
\hline \multicolumn{4}{|l|}{ Annelida } \\
\hline \multirow[t]{2}{*}{ Polychaeta } & Order: Sabellida & 6 & \\
\hline & Unidentified species & 42 & \\
\hline \multicolumn{4}{|l|}{ Mollusca } \\
\hline Bivalvia & Order: Veneroida & 29 & 1 \\
\hline \multirow[t]{2}{*}{ Cephlapoda } & Octopus sp. & & 1 \\
\hline & Order: Teuthida & & 2 \\
\hline \multirow[t]{5}{*}{ Gastropoda } & Fusitriton oregonensis & 9 & 5 \\
\hline & Calliostoma sp. & 7 & 3 \\
\hline & Peltodoris lentiginosa & & 2 \\
\hline & Family: Dendronotidae & 53 & \\
\hline & Superfamily: Aeolidioidea & 26 & \\
\hline \multicolumn{4}{|l|}{ Arthropoda } \\
\hline \multirow[t]{8}{*}{ Malacostraca } & Acantholithodes hispidus & 9 & 2 \\
\hline & Cancer magister & & 8 \\
\hline & Chionoecetes sp. & & 1 \\
\hline & Chlorilia longipes & 5 & 12 \\
\hline & Munida quadraspina & 8393 & 243 \\
\hline & Pandalus platyceros & 250 & 192 \\
\hline & Lopholithodes foraminatus & 4 & \\
\hline & Family: Paguridae & 53 & 3 \\
\hline \multicolumn{4}{|l|}{ Echinodermata } \\
\hline \multirow[t]{6}{*}{ Asteroidea } & Ceramaster sp. & 3 & 1 \\
\hline & Henricia sp. & 4 & 8 \\
\hline & Mediaster aequalis & 7 & 11 \\
\hline & Pteraster tesselatus & 1 & 1 \\
\hline & Pycnopodia helianthoides & 1 & \\
\hline & Solaster sp. & 1 & \\
\hline Holothuroidea & Psolus sp. & 1 & \\
\hline Ophiuroidea & Order: Ophiurida & 51 & \\
\hline \multicolumn{4}{|l|}{ Chordata (Fish) } \\
\hline \multirow[t]{7}{*}{ Osteichthyes } & Family: Agonidae & 3 & \\
\hline & Family: Bathymasteridae & 2 & \\
\hline & Family: Pleuronectidae & 3 & 17 \\
\hline & Sebastes elongatus & 6 & 8 \\
\hline & Sebastes maliger & 7 & 14 \\
\hline & Sebastes sp. & 30 & 37 \\
\hline & Theragra chalcogramma & & 135 \\
\hline \multirow[t]{2}{*}{ Chondrichthyes } & Hexanchus griseus & & 1 \\
\hline & Hydrolagus colliei & 10 & 12 \\
\hline
\end{tabular}

Lyssacine glass sponges (probably Rhabdocalyptus dawsoni, but only 1 sample was collected at Galiano reef; Staurocalyptus and Acanthascus are also found in this area, Leys et al. 2004) were seen growing on and among dead dictyonine skeletons at Howe and Fraser reefs, but at Galiano reef they were only found at the periphery of the population of dictyonine sponges. At Howe reef a dense bed ( $>2$ individuals [ind.] $\mathrm{m}^{-2}$ ) of the sea whip Halipteris willeomoesi was found at the upper northwest perimeter of reef stretching down parallel to the western extent of the reef (Fig. S2A in Supplement 1). There is a clear boundary with no overlap between sea whips and glass sponges for the $\sim 400 \mathrm{~m}$ length of the perimeter. The only soft-bodied animal observed on live dictyonine sponges was the nudibranch Peltodoris lentiginosa (Fig. S2B). Spicules of Aphrocallistes vastus, Heterochone calyx and the encrusting demosponge Desmacella austinii were found in the gut and fecal contents of sampled individuals of $P$. lentiginosa from Galiano reef (J. W. F. Chu pers. obs.). This is the first confirmed predator of a reef-forming glass sponge.

Crustaceans comprised $95 \%$ of all the identified megafauna and, other than Peltodoris lentiginosa, crustaceans were the only animals seen living directly on live reef sponges. The squat lobster Munida quadraspina was the most abundant species overall with densities as high as 75 ind. $\mathrm{m}^{-2}$ at Galiano reef. The longhorn decorator crab Chorilia longipes was seen inside Aphrocallistes vastus oscula decorating itself with live sponge tissue (Fig. S2C). The most common fish observed among the reef sponges were rockfish Sebastes spp., flatfish, ratfish and Alaska pollock Theragra chalcogramma. A bluntnose sixgill shark Hexanchus griseus was also observed at Fraser reef in our 2009 survey. Overall, more fauna were visible in images from the Phantom ROV camera compared with those captured by ROPOS (Table 6).

\section{DISCUSSION}

By using high resolution ROV imagery, GIS analysis and small-scale sampling we found distinct patterns of spatial structure at 3 glass sponge reefs in the Strait of Georgia. Our results also reveal differences in usage of reefs by other animals and our quantified data on sponge abundance allows estimation of water and nutrient processing potential of reefs in the Strait of Georgia and highlight the large effect they have on their environment. 


\section{Differences in sponge density and oscula size}

The density of sponge populations differed substantially at each reef with the densest cover of live sponges at Galiano reef and the least dense cover at Howe reef. This suggests there is proportionally more

Table 5. Differences in the community composition of glass sponges reefs in the Strait of Georgia. Pairwise analysis of similarity (ANOSIM) were used to compare the community composition between reefs using only abundance data from ROPOS 2009 images. Using only Phantom 2008 images, community composition was compared in the presence and absence of glass sponges

\begin{tabular}{|lcc|}
\hline Community comparison & $\mathrm{R}$ & $\mathrm{p}$ \\
\hline ROPOS 2009 & & \\
Howe vs. Fraser & 0.193 & $<0.001$ \\
Howe vs. Galiano & 0.162 & $<0.001$ \\
Fraser vs. Galiano & 0.072 & $<0.001$ \\
Phantom 2008 & & \\
Glass sponge presence vs. absence & 0.246 & $<0.001$ \\
\hline
\end{tabular}

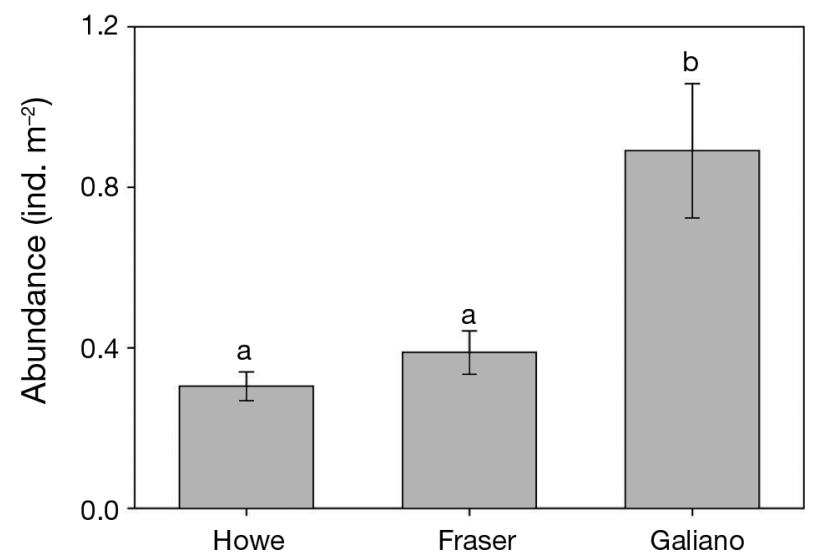

Fig. 9. Comparison of the density of fauna associated with each reef. Counts of fauna were made from ROPOS 2009 images only. Error bars are \pm 1 SE. Different letters above columns indicate a significant difference from others $(\mathrm{p}<0.0001)$ live sponge biomass at Galiano reef compared with Howe and Fraser reefs. Particularly at Howe reef, the live sponges we mapped in 2009 covered far less of the substrate than did the structures identified by multibeam echosounding. Whereas acoustic signals used by multibeam echosounding will penetrate into soft sediment (Medialdea et al. 2008), our sampling only maps live and dead animals above the sediment surface. Therefore, our observations of large expanses of flat sediment between small clusters of sponges suggest sediment accumulation has buried large portions of Howe reef.

Rates of sediment accumulation are highest in front of the Fraser River outflow and in the southern portions of the Strait of Georgia $\left(2.0\right.$ to $\left.2.3 \mathrm{~g} \mathrm{~cm}^{-2} \mathrm{yr}^{-1}\right)$ with less accumulation occurring in Howe Sound and the northern parts of the strait ( $\sim 0.2$ to $0.4 \mathrm{~g} \mathrm{~cm}^{-2} \mathrm{yr}^{-1}$ ) (Johannessen et al. 2003). Although burial of the glass sponges is partially responsible for reef formation (Conway et al. 1991), the burial of sponges at Howe Reef probably occurs at a much slower rate than at Fraser and Galiano reefs. Therefore, the lower surficial cover and density of live sponges at Howe reef and could be due to several factors such as higher loads of suspended sediments, differences in food availability or effects of bottom trawling activity. In general, glass sponges do not occur in regions of high suspended sediments (Leys et al. 2004) because sediments can clog the aquiferous canals (feeding system) of Aphrocallistes vastus (Tompkins-MacDonald \& Leys 2008). Up to $40 \%$ of the bottom sediments in the Strait of Georgia are from terrestrial input of organic matter (Macdonald et al. 1991). The multiple input sources from pulp mills, sewage outfalls and the Fraser River (Macdonald et al. 1991, Yunker et al. 1999, Johannessen et al. 2006, Macdonald et al. 2008) may have detrimentally affected the sponge populations in Howe Sound in the past (Leys et al. 2004). Also, during our survey at Howe reef, we came across areas of mechanically broken sponges scattered across the substrate (Fig. S2D) similar to those described for sponge reefs elsewhere in the Strait of Georgia, where the cause

Table 6. Density of animals in representative phyla in all reefs identified from ROPOS 2009 (RO) and Phantom 2008 (Ph) images. Area represents total area covered from images $\left(\mathrm{m}^{2}\right)$ and reef/area represents the proportion of reef area to surveyed area. Density of animals was standardized to image area (ind. $\mathrm{m}^{-2}$ ) and are grouped by phylum and total fauna. POR: Porifera (not including dictyonine sponges); CNI: Cnidaria; ANN: Annelida; MOL: Mollusca; ART: Arthropoda; ECH: Echinodermata; FISH: fish. Phantom images revealed more fauna due to the higher resolution and slaved strobe of the camera system

\begin{tabular}{|lcrccccccccc|}
\hline Reef & ROV & Area & Reef/area & POR & CNI & ANN & MOL & ART & ECH & FISH & Total \\
\hline Howe & RO & 1167 & 0.09 & 0.0017 & 0.0069 & 0 & 0.0017 & 0.16 & 0.00086 & 0.026 \\
Fraser & RO & 737 & 0.19 & 0.11 & 0.028 & 0 & 0.0054 & 0.14 & 0.0095 & 0.014 \\
Galiano & RO & 532 & 0.39 & 0.0075 & 0.0038 & 0 & 0.015 & 0.31 & 0.026 & 0.070 \\
Galiano & Ph & 385 & 0.28 & 0.45 & 0.031 & 0.12 & 0.32 & 22.6 & 0.18 & 0.13 & 0.31 \\
\end{tabular}




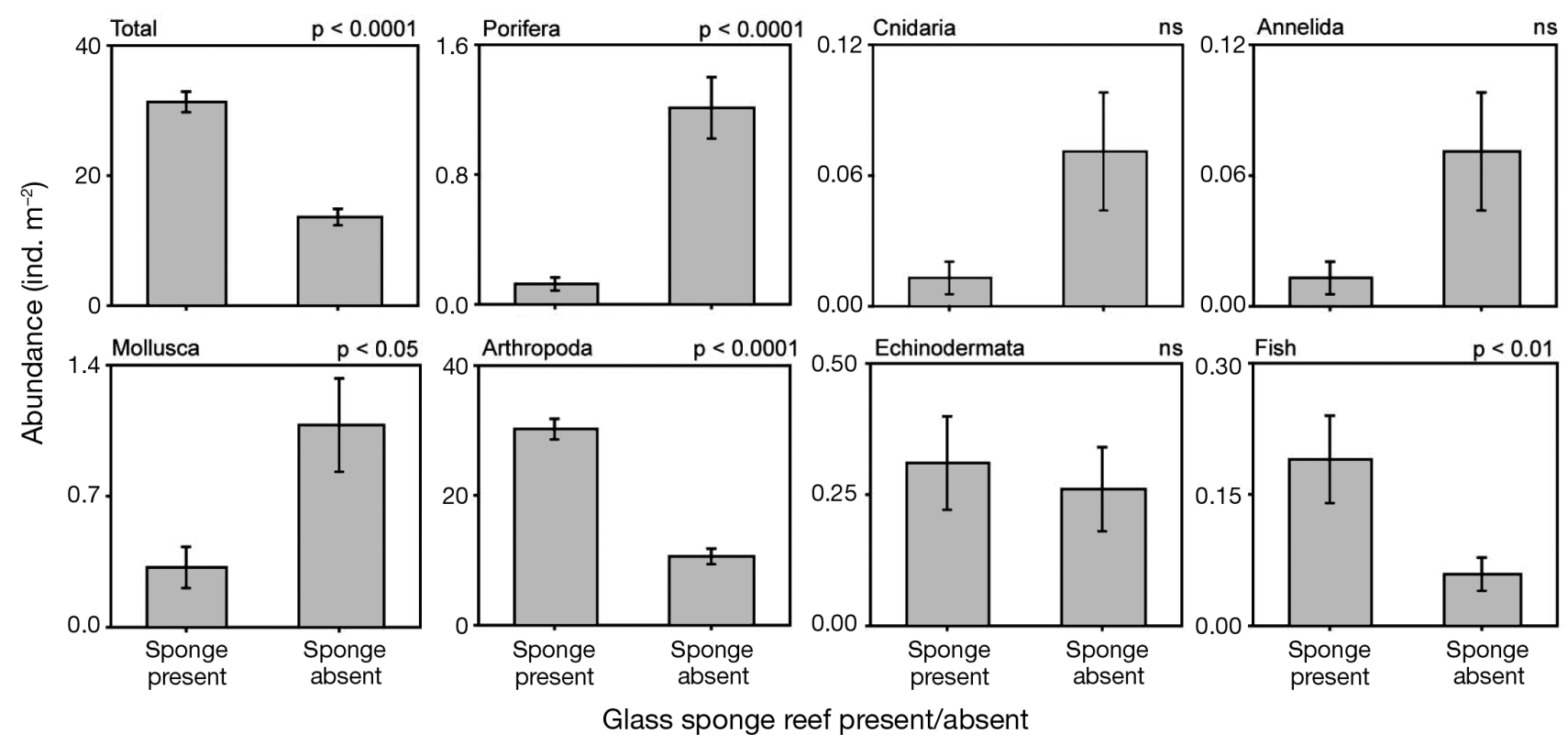

Fig. 10. Comparisons of the abundances of specific phyla at Galiano reef in the presence and absence of reef sponges (live or dead). Counts were made from Phantom 2008 images only. Comparisons include the total (combined fauna) and individual phyla. Error bars are $\pm 1 \mathrm{SE}$; -values indicate significant differences $(\alpha=0.05)$; ns: not significant

was suggested to be bottom trawling (Conway et al. 2007, Cook et al. 2008). We could not obtain access to data on trawling activity in coastal waters, so the exact effect of past trawling on the reefs remains unknown. Although it was not the focus of this study, the potential for anthropogenic impact on the glass sponge populations remains an important topic to address in future studies.

We also found differences in the size of oscula of glass sponges at each of the 3 reefs, with the smallest oscula found at Howe and Galiano reefs and the largest at Fraser reef. Conway et al. (2004) commented in particular on the size of oscula observed at Fraser reef, suggesting they were narrow in comparison with those at the vast northern reefs in Hecate Strait. They suggested that narrow oscula in glass sponges might be an adaptation to high sedimentation rates, but given that we found the smallest oscula in an area of apparently low sediment accumulation (Howe Sound) and larger oscula in areas of comparably higher sediment accumulation (Fraser River outflow and southern Strait of Georgia) (Johannessen et al. 2003), this is not likely to be the case. The difference in the area of oscula more probably reflects the local hydrodynamic patterns as sponge oscula are highly plastic over a gradient of flow velocities (Bidder 1923, Warburton 1960, Palumbi 1986). Small-scale measurements of benthic current velocities would determine whether hydrodynamic patterns are correlated to the variability in sizes of oscula found in reefforming glass sponges.

\section{Spatial structure of sponges within a reef}

At each reef, live glass sponges characteristically form concentric 'hot spots' in localized patches in which sponge recruitment and growth within a patch is substantially higher than in surrounding regions. Our semivariogram analysis and kriging results indicate the spatially dependent distance within a patch is 42,58 and $72 \mathrm{~m}$ at Fraser, Howe and Galiano reefs, respectively, when sampled at a $25 \mathrm{~m}$ grid resolution. When we sampled at twice the resolution at Galiano $(12.5 \mathrm{~m}$ grid), the patch size there was halved to $35 \mathrm{~m}$, yet the structural variance explained by both the 25 and $12.5 \mathrm{~m}$ semivariogram models remained at approximately $80 \%$. This suggests that where sponge density is low (Fraser and Howe reefs) patches are well-defined areas of more or less the same size of what we observe as 'mounds'. However, where sponge density is high, as it is at Galiano reef, spatial structuring occurs at multiple scales. When sampled at $25 \mathrm{~m}$ resolution, patches appear to merge into one another forming large, less defined mounds $72 \mathrm{~m}$ in diameter. When sampled at twice the resolution, smaller patches are resolved. Our data suggest that spatial structuring occurs at even smaller scales and these may be the individual sponge bushes that make up a mound. We do not know to what extent reef sponges may bud, but asexual reproduction is common in the Porifera (Simpson 1984) and budding occurs in other glass sponges (Barthel \& Gutt 1992, Texeido et al. 2006). If a spatially dependent patch maintains a high recruitment of individuals, then the 
coalescence of large bushes would form the continuous clumps of sponges observed in our surveys.

The discontinuity of patches within a reef and the geographic separation of entire reefs mean that sexual reproduction is responsible for dispersal and recruitment of new sponges, but we do not yet know the extent to which budding and recruitment of new larvae are involved in forming a single reef. Although nothing is known about the disperal ability of dictyonine larvae, the larvae of the lyssaccine sponge Oopsacas minuta have been observed to swim much like other sponge larvae in vitro and settle anywhere between $24 \mathrm{~h}$ and $3 \mathrm{wk}$ after release from the parent (S. P. Leys pers. obs.); therefore, it can be presumed that reef sponge larvae may also be retained locally after a short pelagic stage (Maldonado \& Bergquist 2002). Local retention of larvae would further enhance patch structuring and development (Parker \& Tunnicliffe 1994). This conclusion is supported by the observation that juvenile sponges recruit on the dead skeletons of previous generations (Leys et al. 2004, Krautter et al. 2006) and by the strong correlation we found between live sponge cover and dead sponge skeletons.

The reproductive processes of dictyonine sponges may be partially responsible for creating the characteristic patchy structure of the entire living portion of a glass sponge reef. However, the proportion of larval recruitment to asexual budding in a glass sponge reef remains an open question. To this end, we have begun construction of a microsatellite library to compare the genetic relatedness of individuals within a patch, between patches and between reefs. We predict that genetic variability is lowest within a spatially dependent patch with variability increasing as spatial separation between individuals increases.

\section{Reef locations may be determined by hydrodynamics}

At Fraser and Galiano reefs, the narrow depth range at which sponges are found may indirectly indicate where flow acceleration occurs over the underlying bathymetry. The lack of a correlation with slope is not surprising as dense nonreef populations of Aphrocalliste vastus and Heterochone calyx are also found on near vertical fjord walls (Leys et al. 2004, Yahel et al. 2007), yet depth was a strong predictor of glass sponge distributions. At each reef the band of live sponges was within a narrow range of depths and slopes found near the crest of their respective underlying bathymetric feature (ridge or mound). We suggest this is primarily due to flow patterns at that depth in the SOG. When water flows over bathymetric 'bumps', it is forced to converge over the ridge, accelerating the fluid at the upper regions of the leeward side which creates a zone of stagnant water at the lower regions of the leeward side (Dewey et al. 2005). We expect this to be the case at Fraser reef because water flows over the Fraser Ridge in a northern direction ( $\mathrm{R}$. Thomson, Institute of Ocean Sciences, pers. comm.) and glass sponges occur on the leeward side of the Fraser Ridge where current velocities are also the highest at the flood tides (J. Bedard, University of Victoria, pers. obs.). Leeward side habitats may also act as a shelter from the high suspended sediment loads circulated in the Strait of Georgia. At Galiano reef the live sponges were found on both sides of the ridge where the flow occurs in a predominantly southeastern direction ( $R$. Thomson pers. comm.). Because the flow runs parallel to the crest of the ridge, localized small-scale upwellings occur along the ridge; this kind of upwelling may explain the distributions of sponges on both sides of the ridge. Topographic amplificaiton of flow explains the increased abundance of other communities of sessile suspension feeders, such as corals (Sebens 1984, Genin et al. 1986). The increased current velocities are beneficial by removing discharged waste waters and replenishing source waters for suspension feeding (Vogel 1994), which is especially advantageous for the high oscula densities found at reefs as higher flow decreases the probability of adjacent sponges drawing in prefiltered water.

The low percentage of live sponge cover at Howe reef may reflect the suboptimal flow patterns in this area. The relative current velocities at Howe reef are the slowest of the 3 reefs and currents flow in a northwestern direction (R. Thomson pers. comm.) The low current velocity, lack of topographic amplification and low sponge cover suggest that this reef exists at the lowest tolerable thresholds of flow, but persists because the sedimentation rates here are also low relative to the areas near the Fraser and Galiano reefs (Johannessen et al. 2003). The unique bathymetry at the locations where live sponges are found indicates that reefs require a specific ecological niche. A balance of high flow and low sedimentation rates, enough to cement the reef but not completely bury the sponges, are the strongest abiotic predictors of where glass sponge reefs can exist.

\section{Associations of megafauna with sponge reefs}

Where glass sponges dominate the benthic biomass, they have been shown to increase local megafauna abundance by modifying the otherwise soft and flat benthos (Dayton et al. 1974, Barthel 1992a,b, Bett \& Rice 1992). Our results show that glass sponge reefs also form a massive habitat for other invertebrates and fish. The abundance of megafauna was highest at 
Galiano reef, which also had the greatest sponge cover and highest density of oscula. Crustaceans such as Munida quadraspina, decorator crabs and large lithodid crabs were the predominant taxa using the sponges as refuge by hiding in oscula of live and dead sponges and sitting on top of live sponges to feed (J. W. F. Chu pers. obs.). Sebastes spp. rockfish also were seen among the glass sponges, using them as refuge (Cook et al. 2008, Marliave et al. 2009) either from predators or perhaps from the high flow above the reef.

Interestingly, glass sponge density does not correlate with an increase in all phyla, as other sponges and certain molluscs appear to be excluded by glass sponges. Demosponges were only found on the periphery of large glass sponge mounds, and it may be that these much smaller individuals are excluded by dictyonine sponges in competition for filtering the same body of water. The majority of molluscs seen were small dendronotid and aeolid nudibranchs and these were usually on the bare substrate between areas of glass sponges or on hydroids growing on dead sponges. Pinnular hexactin spicules of both Aphrocallistes vastus and Heterochone calyx have a barbed ornamental ray that protrudes outwards from the outer dermal surface that dislodge and impale soft tissue on contact (Austin 2003) so that soft-bodied invertebrates may avoid the surface of live glass sponges. The hard exoskeletons of crustaceans and the scales of fish are not damaged by glass sponge spicules and these, not surprisingly, were the only taxa observed in physical contact with live sponges. The only exception to this was the dorid nudibranch Peltodoris lentiginosa, which we found commonly on $A$. vastus and $H$. calyx and, which gut and fecal content analyses showed, was eating the sponges (J. W. F Chu pers. obs.). Although nudibranchs often eat sponges, only one other record shows they eat hexactinellids (Dayton et al. 1974). Nudibranch and asteroid predators play integral roles in shaping the Antarctic glass sponge populations. In glass sponge reefs, the asteroids Pteraster tesselatus and Mediaster sp. may also prey on A. vastus and $H$. calyx, as P. tesselatus has been observed to feed on the lyssacine sponge Rhabdocalyptus dawsoni found with A.vastus (Leys \& Lauzon 1998, Leys et al. 2007).

Past studies on the community structure of reefs in the Strait of Georgia suggested increased megafauna abundance in association with the glass sponges across all taxa (Cook et al. 2008, Marliave et al. 2009). However, these studies lacked the statistical analyses to determine whether their results were free from observational bias or occurred by random chance alone. Our results revealed the positive and negative associations within the community of animals associated with glass sponges, and if we take into account the distinct spatial patterns of the glass sponges, it is reasonable to assume that the distributions of megafauna are heavily influenced by the patchiness of glass sponges within a reef. In areas of high sponge density, fauna that use sponges will probably form a separate community from the fauna excluded by competition with hexactinellids.

\section{Estimates of benthopelagic coupling}

Our high resolution survey of the density of sponges and oscula at Galiano reef, coupled with known pumping and feeding rates for Aphrocallistes vastus (Yahel et al. 2006, 2007) allows us to highlight the volume of water and the amounts of carbon and nitrogen processed at a reef. Glass sponges can remove up to $99 \%$ of the ultraplankton from the water at excurrent (pumping) velocities of $0.01 \mathrm{~m} \mathrm{~s}^{-1}$ (Yahel et al. 2007). From our measurements of average oscula size and live sponge cover, the entire area we surveyed at Galiano reef would process water at $83000 \mathrm{l} \mathrm{s}^{-1}$. This estimate assumes continuous pumping conditions and similar rates from the closely related Heterochons calyx. Based on in situ measurements of nearby populations of $A$. vastus (Yahel et al. 2007) total organic carbon (TOC) removal and nitrogen excretion rates would be $0.96 \mathrm{~g}$ $\mathrm{C} \mathrm{m}^{-2} \mathrm{~d}^{-1}$ and $0.16 \mathrm{~g} \mathrm{~N} \mathrm{~m}^{-2} \mathrm{~d}^{-1}$, respectively, at Galiano reef. Nutrient flux would probably be greater within the hot spots of sponge density because our conservative approach averages nutrient flux over the entire benthic area we covered in our survey. Our carbon uptake calculations greatly exceed those for other glass sponge populations (Pile \& Young 2006, Yahel et al. 2007) and, among sponge communities, are only surpassed by calculations for populations of Baikalospongia bacillifera in Lake Baikal, Russia (Pile et al. 1997).

\section{SUMMARY}

Our small-scale sampling coupling high resolution imagery and ROVs has allowed us to establish the biological patterns live glass sponges create within their ecosystem. The 'patchiness' of reefs may reflect recruitment and growth, allowing us to formulate the hypothesis that sponges within reefs are more closely related to one another compared with those at other reefs. Sponge cover and density is different between reefs, but regardless of sponge density, more crustaceans and fish are found when glass sponges are present. The scale and scope of our study focussed on only a small fraction of the total area covered by known glass sponge reefs. The reefs we studied cover several hundred thousand square metres, but are dwarfed by the 4 large reefs in Hecate Strait in north- 
ern British Columbia, which cover a 1300-fold greater area. A larger quantified survey coupled with a conservative extrapolation of our findings may reveal significant large scale effects of glass sponges on the abundance of megafauna and nutrient cycling along the western Canadian continental shelf.

Acknowledgements. We thank H. M. Reiswig, G. Yahel, J. Roland and K. Conway for fruitful discussions. K. Conway kindly provided bathymetric data and shared knowledge of the reefs. R. Thomson helped immensely by providing his detailed knowledge on benthic flow patterns in the Strait of Georgia. We thank H. M. Reiswig for identifying sponge species from voucher specimens and G. Yahel for help with the multivariate analyses. G. Yahel, A. Chaves-Fonnegra, E. Adams, A. Riesgo, D. Ludeman, J. Bedard, N. Forget and M. Matabos helped with field work. We are also grateful to J. Boutillier, W. Carolsfeld, J. Pegg and the Pacific Biological Station (Fisheries and Oceans Canada) for their gift of ship time with the CCGS Neocaligulus and use of their Phantom HD2+2 ROV for portions of this work. Finally, we thank the entire ROPOS team and the captains and crew of the CCGS Vector, CCGS Neocaligulus and CCGS JP Tully for survey, sampling and technical support. C. Nielsen provided invaluable GIS instruction. A. Riesgo, M. W. Wonham and G. Yahel provided feedback on early manuscript drafts. Funding came from Bamfield Marine Sciences Centre and University of Alberta graduate student teaching assistantships and a Queen Elizabeth II scholarship to J.W.F.C and Natural Sciences and Engineering Research Council (NSERC) Ship Time and NSERC Discovery Program grants to S.P.L.

\section{LITERATURE CITED}

Austin WC (2003) Sponge gardens: a hidden treasure in British Columbia. www.mareco.org/khoyatan/spongegardens

Barrie JV, Hill PR, Conway KW, Iwanowska K, Picard K (2005) Georgia Basin: seabed features and marine geohazards. Geosci Can 32:145-156

Barry JP, Dayton PK (1988) Current patterns in McMurdo Sound, Antarctica and their relationship to local biotic communities. Polar Biol 8:367-376

Barthel D (1992a) Do hexactinellids structure Antarctic sponge associations? Ophelia 36:111-118

Barthel D (1992b) Antarctic hexactinellids: a taxonomically difficult, but ecologically important benthic component. Verh Dtsch Zool Ges 85:271-276

Barthel D, Gutt J (1992) Sponge associations in the eastern Weddell Sea. Antarct Sci 4:137-150

Bett BJ, Rice AL (1992) The influence of hexactinellid sponge (Pheronema carpenteri) spicules on the patchy distribution of macrobenthos in the Porcupine Seabight (bathyal NE Atlantic). Ophelia 36:217-226

Beyer HL (2004) Hawth's analysis tools for ArcGIS. www. spatialecology.com/htools (accessed 1 Nov 2009)

Bidder GG (1923) The relation of the form of a sponge to its currents. Q J Microsc Sci 67:293-323

Burd BJ, Barnes PAG, Wright CA, Thomson RE (2008) A review of subtidal benthic habitats and invertebrate biota of the Strait of Georgia, British Columbia. Mar Environ Res 66:S3-S38

Conway KW, Barrie JV, Austin WC, Luternauer JL (1991) Holocene sponge bioherms on the western Canadian continental shelf. Cont Shelf Res 11:771-790
Conway KW, Krautter M, Barrie JV, Neuweiler M (2001) Hexactinellid sponge reefs on the Canadian continental shelf: a unique 'living fossil'. Geosci Can 28:71-78

Conway KW, Barrie JV, Krautter M (2004) Modern siliceous sponge reefs in a turbid, siliciclastic setting: Fraser River delta, British Columbia, Canada. Neues Jahrb Geol Palaeont Monatsh 6:335-350

Conway KW, Barrie JV, Krautter M (2005) Geomorphology of unique reefs on the western Canadian shelf: sponge reefs mapped by multibeam bathymetry. Geo-Mar Lett 25: $205-213$

Conway KW, Barrie JV, Hill, PR, Austin WC, Picard K (2007) Mapping sensitive benthic habitats in the Strait of Georgia, coastal British Columbia: deep-water sponge and coral reefs. Geol Surv Can 2007-A2:1-6

Cook SE (2005) Ecology of the hexactinellid sponge reefs on the Western Canadian continental shelf. MSc thesis, University of Victoria

Cook SE, Conway KW, Burd B (2008) Status of the glass sponge reefs in the Georgia Basin. Mar Environ Res 66(Suppl 1):S80-S86

> Dayton PK, Robilliard GA, Paine RT, Dayton LB (1974) Biological accommodation in the benthic community at McMurdo Sound, Antarctica. Ecol Monogr 44:105-128

> Dewey R, Richmond D, Garrett C (2005) Stratified tidal flow over a bump. J Phys Oceanogr 35:1911-1927

> Genin A, Dayton PK, Lonsdale PF, Spiess FN (1986) Corals on seamount peaks provide evidence of current acceleration over deep-sea topography. Nature 322:59-61

Ghiold J (1991) The sponges that spanned Europe. New Sci 2:58-62

> Grassle JT (1991) Deep-sea benthic biodiversity. Bioscience 41:464-469

> Hill PR, Conway K, Lintern DG, Meule S, Picard K, Vaughn Barrie J (2008) Sedimentary processes and sediment dispersal in the southern Strait of Georgia, BC, Canada. Mar Environ Res 66(Suppl 1):S39-S48

Johannessen SC, Macdonald RW, Paton DW (2003) A sediment and organic carbon budget for the greater Strait of Georgia. Estuar Coast Shelf Sci 56:845-860

> Johannessen SC, Masson D, Macdonald RW (2006) Distribution and cycling of suspended particles inferred from transmissivity in the Strait of Georgia, Haro Strait and Juan de Fuca Strait. Atmosphere-Ocean 44:17-27

> Krautter M, Conway KW, Barrie JV, Neuweiler M (2001) Discovery of a 'living dinosaur': globally unique modern hexactinellid sponge reefs off British Columbia, Canada. Facies 44:265-282

Krautter M, Conway KW, Barrie JV (2006) Recent hexactinosidan sponge reefs (silicate mounds) off British Columbia, Canada: frame-building processes. J Paleontol 80:38-48

> Legendre P, Thrush SF, Cummings VJ, Dayton PK and others (1997) Spatial structure of bivalves in a sandflat: scale and generating processes. J Exp Mar Biol Ecol 216:99-128

> Leinfelder RR, Krautter M, Laternser R, Nose M and others (1994) The origin of Jurassic reefs: current research developments and results. Facies 31:1-56

Levin SA (1992) The problem of pattern and scale in ecology: the Robert A. MacArthur award lecture. Ecology 73:1943-1967

Leys SP, Lauzon NRJ (1998) Hexactinellid sponge ecology: growth rates and seasonality in deep water sponges. J Exp Mar Biol Ecol 230:111-129

Leys SP, Wilson K, Holeton C, Reiswig HM, Austin WC, Tunnicliffe V (2004) Patterns of glass sponge (Porifera, Hexactinellida) distribution in coastal waters of British Columbia Canada. Mar Ecol Prog Ser 283:133-149

Leys SP, Mackie GO, Reiswig HM (2007) The biology of glass 
sponges. Adv Mar Biol 52:1-145

Macdonald RW, Macdonald DM, O'Brien MC, Gobeil C (1991) Accumulation of heavy metals ( $\mathrm{Pb}, \mathrm{Zn}, \mathrm{Cu}, \mathrm{Cd})$, carbon and nitrogen in sediments from Strait of Georgia. Mar Chem 34:109-135

Macdonald RW, Johannessen SC, Gobeil C, Wright C, Burd B, Van Roodselaar A, Pedersen TF (2008) Sediment redox tracers in Strait of Georgia sediments - Can they inform us of the loadings of organic carbon from municipal wastewater? Mar Environ Res 66(Suppl 1):S87-S100

Maldonado M, Bergquist PR (2002) Phylum Porifera. In: Young CM (ed) Atlas of marine invertebrate larvae. Academic Press, London

Marliave JB, Conway KW, Gibbs DM, Lamb A, Gibbs C (2009) Biodiversity and rockfish recruitment in sponge gardens and bioherms of southern British Columbia, Canada. Mar Biol 156:2247-2254

Medialdea T, Somoza L, León R, Farrán M and others (2008) Multibeam backscatter as a tool for sea-floor characterization and identification of oil spills in the Galicia Bank. Mar Geol 249:93-107

Palumbi SR (1986) How body plans limit acclimation: responses of a demosponge to wave force. Ecology 67: 208-214

> Parker T, Tunnicliffe V (1994) Disperal strategies of the biota on an oceanic seamount: implications for ecology and biogeography. Biol Bull (Woods Hole) 187:336-345

Pile AJ, Young CM (2006) The natural diet of a hexactinellid sponge: benthic-pelagic coupling in a deep-sea microbial food web. Deep-Sea Res I 53:1148-1156

Pile AJ, Patterson MR, Savarese M, Chernykh VI, Fialkov VA (1997) Trophic effects of sponge feeding within Lake Baikal's littoral zone. 2. Sponge abundance, diet, feeding efficiency, and carbon flux. Limnol Oceanogr 42:178-184

Reiswig HM (2006) Classification and phylogeny of Hexactinellida (Porifera). Can J Zool 84:195-204

Robertson GP, Huston MA, Evans FC, Tiedje JM (1988) Spatial variability in a successional plant community: patterns of nitrogen availability. Ecology 69:1517-1524

Rossi RE, Mulla DJ, Journel AG, Franz EH (1992) Geostatisti-

Editorial responsibility: Pei-Yuan Qian,

Kowloon, Hong Kong SAR cal tools for modeling and interpreting ecological spatial dependence. Ecol Monogr 62:277-314

Sebens KP (1984) Water flow and coral colony size: interhabitat comparisons of the octocoral Alcyonium siderium. Proc Natl Acad Sci USA 81:5473-5477

Simpson TL (1984) The cell biology of sponges. SpringerVerlag, New York

Tabachnick KR (1994) Distribution of recent Hexactinellida. In: van Soest $R$, van Kempen B, Braekman G (eds) Sponges in time and space. Balkerna, Rotterdam

Teixido N, Gili JM, Uriz MJ, Gutt J, Arntz WE (2006) Observations of asexual reproductive strategies in Antarctic hexactinellid sponges from ROV video records. Deep-Sea Res II 53:972-984

Thomson RE (1981) Oceanography of the British Columbia coast. Can Spec Publ Fish Aquat Sci 56, Ottawa

Tompkins-MacDonald GJ, Leys SP (2008) Glass sponges arrest pumping in response to sediment: implications for the physiology of the hexactinellid conduction system. Mar Biol 154:973-984

Vogel SV (1994) Life in moving fluids: the physical biology of flow. Princeton University Press, Princeton, NJ

- Warburton FE (1960) Influence of currents on form of sponges. Science 132:89

Whitney F, Conway K, Thomson R, Barrie JV, Krautter M, Mungov G (2005) Oceanographic habitat of sponge reefs on the Western Canadian Continenal Shelf. Cont Shelf Res 25:211-226

Yahel G, Eerkes-Medrano DI, Leys SP (2006) Size independent selective filtration of ultraplankton by hexactinellid glass sponges. Aquat Microb Ecol 45:181-194

Yahel G, Whitney F, Reiswig HM, Eerkes-Medrano DI, Leys SP (2007) In situ feeding and metabolism of glass sponges (Hexactinellida, Porifera) studied in a deep temperate fjord with a remotely operated submersible. Limnol Oceanogr 52:428-440

Yunker MB, Macdonald RW, Goyette D, Paton DW, Fowler BR, Sullivan D, Boyd J (1999) Natural and anthropogenic inputs of hydrocarbons to the Strait of Georgia. Sci Total Environ 225:181-209

Submitted: June 24, 2010; Accepted: August 29, 2010 Proofs received from author(s): October 20, 2010 